\title{
biomolecules
}

ISSN 2218-273X

www.mdpi.com/journal/biomolecules/

Review

\section{Interactions between Calcium and Alpha-Synuclein in Neurodegeneration}

\author{
Alex Rcom-H'cheo-Gauthier ${ }^{\dagger}$, Jacob Goodwin ${ }^{\dagger}$ and Dean L. Pountney* \\ Griffith Health Institute, School of Medical Science, Griffith University, Gold Coast, Queensland 4222, \\ Australia; E-Mails: alexandre.rcom-hcheo-gauthier@griffithuni.edu.au (A.R.-H.-G.); \\ j.goodwin@griffith.edu.au (J.G.) \\ $\dagger$ These authors contributed equally to this work. \\ * Author to whom correspondence should be addressed; E-Mail: d.pountney@griffith.edu.au; \\ Tel.: +61-7-5552-7273; Fax: +61-7-5552-8908.
}

Received: 26 March 2014; in revised form: 25 June 2014 / Accepted: 14 July 2014 /

Published: 14 August 2014

\begin{abstract}
In Parkinson's disease and some atypical Parkinson's syndromes, aggregation of the $\alpha$-synuclein protein ( $\alpha$-syn) has been linked to neurodegeneration. Many triggers for pathological $\alpha$-syn aggregation have been identified, including port-translational modifications, oxidative stress and raised metal ions, such as $\mathrm{Ca}^{2+}$. Recently, it has been found using cell culture models that transient increases of intracellular $\mathrm{Ca}^{2+}$ induce cytoplasmic $\alpha$-syn aggregates. $\mathrm{Ca}^{2+}$-dependent $\alpha$-syn aggregation could be blocked by the $\mathrm{Ca}^{2+}$ buffering agent, BAPTA-AM, or by the $\mathrm{Ca}^{2+}$ channel blocker, Trimethadione. Furthermore, a greater proportion of cells positive for aggregates occurred when both raised $\mathrm{Ca}^{2+}$ and oxidative stress were combined, indicating that $\mathrm{Ca}^{2+}$ and oxidative stress cooperatively promote $\alpha$-syn aggregation. Current on-going work using a unilateral mouse lesion model of Parkinson's disease shows a greater proportion of calbindin-positive neurons survive the lesion, with intracellular $\alpha$-syn aggregates almost exclusively occurring in calbindin-negative neurons. These and other recent findings are reviewed in the context of neurodegenerative pathologies and suggest an association between raised $\mathrm{Ca}^{2+}, \alpha$-syn aggregation and neurotoxicity.
\end{abstract}

Keywords: alpha-synuclein; Parkinson's disease; calcium; multiple system atrophy; neurodegeneration; oxidative stress 


\section{Introduction}

\subsection{Neurodegeneration and $\alpha$-Synuclein}

Under normal cellular conditions, proteins have a stable fold that is appropriate to perform their biological function. In general, misfolded proteins that cannot be refolded are degraded by the ubiquitin proteasome system (UPS), or via lysosomal degradation. In disease, however, the misfolded protein may be resistant to degradation and undergo aggregate formation. Abnormal aggregation of the protein $\alpha$-synuclein ( $\alpha$-syn) has been implicated in a number of neurological diseases, including Parkinson's disease (PD), characterised by cytoplasmic aggregates in multiple cell types throughout the central nervous system. Collectively, these diseases are termed $\alpha$-synucleinopathies and include PD and the atypical Parkinson's syndrome, multiple system atrophy (MSA). In this report, key features of PD and MSA will be reviewed, two diseases that characterize the range of cell types affected by $\alpha$-syn aggregates. Moreover, mechanisms of and factors influencing $\alpha$-syn aggregation in the CNS will be discussed, with a special emphasis on the role of $\mathrm{Ca}^{2+}$ interactions [1-3].

\subsection{Parkinson's Disease and $\alpha$-Synuclein}

PD has progressive clinical symptoms, including slight weakness, tremors, forward posture, sleep disturbance, constipation, the inability to walk unaided, speech impairment, difficulty swallowing, tremor, loss of urinary and gastrointestinal control and extreme exhaustion. The three main symptoms of PD are bradykinesia, or a slowing of voluntary controlled movement, rigidity, and tremor. Pathological examination of brain tissues from PD sufferers shows that there is a loss of dopaminergic neurons in the Substantia nigra (SN), a region of the brain that, through neural connections with the striatum, is responsible for controlled muscle movements. PD can be classified into two main groups: idiopathic and familial. Idiopathic PD, the larger of the two groups, accounts for roughly $85 \%-90 \%$ of all PD cases. Familial PD accounts for the remaining $10 \%-15 \%$ of cases and is due to mutations in a number of genes, including SNCA (PARK1/4), the gene responsible for the expression of $\alpha$-syn. To date, five PD-linked point mutations in $S N C A$, have been identified [1], comprising the A30P [4], A53T [5], E46K [6], G51D [7] and H50Q [8] amino acid substitutions that disrupt the neurotransmitter vesicle binding domain (see Figure 1). The A53T and A30P mutations also affect the response to oxidative stress with expression of these mutant isoforms significantly increasing cytotoxicity induced by hydrogen peroxide and 1-methyl-4-phenylpyridinium $\left(\mathrm{MPP}^{+}\right)$in comparison to cells expressing wild-type $\alpha$-syn and control cells [9]. Moreover, the A30P, A53T and H50Q mutations result in increased oligomerization and fibril formation compared to wild-type [10,11]. Furthermore, gene duplication [12] and triplication of $\alpha$-syn [13] have also been found in familial PD, implicating gene dosage effects in pathogenesis.

\subsection{Parkinson's Disease and Environmental Factors}

Environmental factors, such as exposure to pesticides and insecticides, may play a role in the pathogenesis of idiopathic PD. Rotenone, 1-methyl-4-phenylpyridinium (MPP+) and Paraquat have all been linked to PD [14,15]. These chemicals generate oxidative stress through the inhibition of complex I of the mitochondrial electron transport chain (rotenone, MPP+) or by acting as a general inducer of 
reactive oxygen species (ROS) (paraquat). Interestingly, two environmental factors have the opposite affect and are protective for PD. Cigarette smoking and caffeine have both been shown to be protective [16], and while the mechanism of caffeine protection is unclear the caloric restriction associated with smoking with a subsequent decrease in metabolic oxidative stress may be a factor.

Figure 1. $\alpha$-Synuclein protein ( $\alpha$-syn) domain structure. $\alpha$-Syn contains three putative domains. KTK repeats in the $N$-terminus are involved in lipid interaction, the hydrophobic NAC domain is important for aggregation and the $\mathrm{C}$-terminal $\mathrm{Ca}^{2+}$ binding site can increase the rate of oligomerization [1,2]. The Parkinson's disease (PD)-linked point mutations are indicated within the neurotransmitter vesicle binding domain.

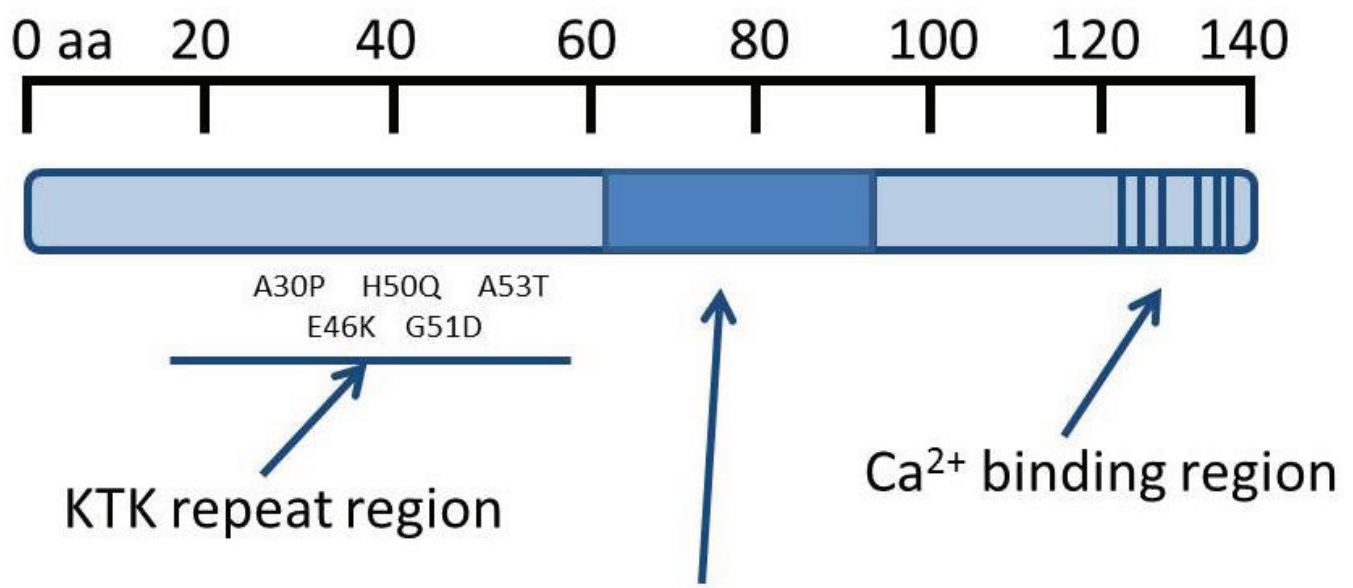

Hydrophobic NAC domain

\subsection{Pathology of Parkinson's Disease and Multiple System Atrophy}

A characteristic pathological feature of PD is a severe loss of the neuromelanin-positive dopaminergic neurons of the SN, located in the midbrain. Signalling between the SN and the striatum is involved in controlling muscle movements; therefore the resultant loss of nigro-striatal pathway signalling can explain the classical symptoms of PD. Of the neurons that remain, large protein aggregates called Lewy bodies (LB) are often observed. While LB's are made up of numerous proteins, including proteasome components, lysosome components and chaperone proteins, $\alpha$-syn immunoreactivity defined $\alpha$-syn as a major component of the LB in PD and in dementia with Lewy bodies [1,17].

Multiple system atrophy (MSA) is also late onset, neurodegenerative, idiopathic and progressive [3]. However unlike PD, where aggregates form in neuronal cells, $\alpha$-syn positive protein inclusions are formed within the cytoplasm of oligodendrocytes and are therefore termed glial cytoplasmic inclusions (GCI). MSA also differs from PD in the distribution of these cytoplasmic aggregates throughout the central nervous system where in addition to the $\mathrm{SN}$, the locus coeruleus, putamen, inferior olives, pontine nuclei, Purkinje cells and the intermediolateral columns of the spinal cord are also affected. Classified into two subgroups, MSA-P (Parkinsonian) is characterized by GCIs within the SN, which results in the Parkinsonian symptoms, whereas, MSCA-C (cerebellar ataxia) affects the cerebellum and results in gait and limb ataxia and oculomotor disturbances. In each sub-type, the severity and type of symptoms is dependent on the distribution and density of $\alpha$-syn inclusions. MSA has no strong genetic link, although a number of single nucleotide polymorphisms, including the SNCA gene, have been 
identified with an increased risk of MSA [18]. A number of studies have looked at environmental and other risk factors for MSA, although with no consensus findings $[19,20]$.

\subsection{Properties of $\alpha$-Synuclein}

$\alpha-S y n$ is a $14 \mathrm{kDa}$ protein encoded by the $S N C A$ gene that is highly conserved in vertebrate species. Although the exact role of $\alpha$-syn remains unclear, the protein is primarily expressed in the olfactory bulb, frontal cortex, striatum and the hippocampus with lower expression levels also observed in the hypothalamus, thalamus, midbrain, cerebellum and pons [21] where it localises to presynaptic terminals of dopaminergic neurons [22,23]. It is believed to be involved in neurotransmitter vesicle recycling and dopamine neurotransmission through interaction with soluble NSF attachment protein receptor (SNARE) [24]. Three putative domains of the $\alpha$-syn protein have been identified (see Figure 1). The N-terminal domain comprises seven 11 amino acid imperfect repeat sequences, predicted to form aliphatic helices (KTK repeats) allowing $\alpha$-syn to associate with lipid membranes. The C-terminal domain contains a number of acidic residues identified as a $\mathrm{Ca}^{2+}$ binding site [25]. The third domain (NAC domain) contains hydrophobic amino acids and is important for aggregation [26]. The conformation of $\alpha$-syn is highly dependent on environmental conditions. In the aqueous cellular environment, $\alpha$-syn adopts a random coiled structure, but adopts a helical conformation upon binding to acidic phospholipid vesicles [27-29]. $\alpha$-Syn is also prone to nucleation dependent aggregation [30] through the N-terminus [31] and this aggregation, inhibited upon membrane binding, transforms $\alpha$-syn from the random coiled conformation to beta-pleated sheets [32,33]. Deletion of the hydrophobic 12 aa central region of $\alpha$-syn results in the loss of $\alpha$-syn aggregation and the hydrophobic 12 aa region alone is sufficient to form aggregates. The $\alpha$-syn protein has been shown to interact with membranes [34] and both the N- and C-terminus of the protein can be bound to membranes. This membrane interaction, and the function as a SNARE associated protein is mediated by Rab3a [35].

Gene triplication and duplication of $S N C A$ in autosomal dominant forms of PD suggests the importance of $\alpha$-syn gene dosage and protein concentration in aggregation. Interestingly, mouse studies have shown that there is an age-dependent decline in both $\alpha$-syn protein and mRNA levels [36]. Whereas, analysis of single dopaminergic neurons from tissue of PD affected individuals and controls have revealed that there is a significant increase in $\alpha$-syn mRNA levels [37].

\section{6. $\alpha$-Synuclein Oligomerization and Cytotoxicity}

Abnormal oligomeric $\alpha$-syn species have been implicated in the pathogenesis of $\alpha$-synucleinopathies [38-43]. Danzer and co-workers found that small annular $\alpha$-syn species but not monomeric protein were able to increase cytosolic $\mathrm{Ca}^{2+}$ levels in SH-SY5Y cells [43]. This increase of cytosolic $\mathrm{Ca}^{2+}$ was rapid, reaching a plateau around $200 \mathrm{~s}$, and dependent on extracellular $\mathrm{Ca}^{2+}$, indicating a pore forming ability of $\alpha$-syn oligomeric species. Treatment with $\alpha$-syn oligomers resulted in an increased level of cleaved (active) caspase 3 indicating $\alpha$-syn olimomers induced apoptosis. Outeiro et al. [38] used protein fragment complementation assay (PCA) and bimolecular fluorescence complementation (BiFC) assay to monitor $\alpha$-syn monomer interaction in vitro and determined that the most favourable $\alpha$-syn interaction was anti-parallel, resulting in cytotoxicity that could be suppressed by HSP70. 
One possible mechanism for increased rate of $\alpha$-syn oligomerization is an increase in mitochondrial mediated ROS production. Using PD cybrids, which have relatively high levels of oxidative stress and an enhancement in oligomer formation, treatment with CoQ10 and GSH antioxidants resulted in a decrease in oligomer formation [39]. Moreover, $\alpha$-syn oligomer association with mitochondria may be linked to mitochondrial dysfunction [42]. Recently, using both non-denaturing gel electrophoresis and MALDI-TOF mass spectroscopy, $\alpha$-syn has been shown to exist as $\alpha$-syn tetramers in M17D, HEK293, HeLa and COS-7 cells [44,45], with predominantly helical structure. These normally occurring tetramers are proposed to be non-toxic, with the abnormal, toxic oligomeric species produced via interconversion first to the monomer.

\section{7. $\alpha$-Synuclein Post-Translational Modifications}

Phosphorylation of $\alpha$-syn has been shown to be important in increasing the rate of aggregation [46] and has also been shown to aid metal ion association $[47,48]$. Truncation and proteolytic processing of $\alpha$-syn have also been implicated in aggregate pathology [49]. Oxidation leads to other common post-translational modifications, including nitrosylation, and it has been shown that oxidative stress can stabilise oligomeric $\alpha$-syn species via the formation of di-tyrosine cross links [50,51]. However, oxidation of recombinant human $\alpha$-syn results primarily in oxidation of methionine residues [52] and at normal physiological $\mathrm{pH}$ this oxidation abolishes $\alpha$-syn aggregation [53]. One of the most striking characteristics of PD is the selective loss of dopaminergic neurons in the SN which has been mimicked in a drosophila model system [54]. However, $\alpha$-syn has been shown to play a cyto-protective role in dopaminergic cells. The N27 dopaminergic cell line transfected with human $\alpha$-syn is protected against $\mathrm{MPP}+$ induced apoptosis via inhibition of $\mathrm{PKC} \delta$ cleavage and inhibition of $\mathrm{BAD}$, and the concentration of ROS is reduced, in comparison to non-transfected cells [55]. Dopamine has also been shown to inhibit the formation of $\alpha$-syn fibrils via oxidative modification of the protein and enhances formation of protofibrillar $\alpha$-syn species [56].

\subsection{Exosomes and the Cell to Cell Spread of $\alpha$-Synuclein}

One factor contributing to the toxicity of oligomeric $\alpha$-syn species is cell to cell spread of $\alpha$-syn via exosomes [57]. Exosomes are membranous vesicles released from mammalian cells and have been shown to contain mRNA, microRNA and proteins. Alvarez-Erviti et al. [58] demonstrated that $\alpha$-syn positive exosomes isolated from a SHSY-5Y neuroblastoma $\alpha$-syn overexpressing cell line were capable of transferring the protein to other SHSY-5Y cells. They also concluded that inhibition of the lysosomes that are involved in $\alpha$-syn degradation resulted in an increase in $\alpha$-syn exosome-mediated release into the culture media. Danzer et al. [59] demonstrated in H4 cells and primary cortical neurons that $\alpha$-syn in exosomes was oligomeric. They also deduced that $\alpha$-syn was predominantly either outside or associated with the outer membrane of the exosome, but not totally excluded from the lumen. Furthermore, processing of disease-associated $\alpha$-syn in the human brain is consistent with prion-like cell-to-cell spread [60]. Microglial cells have also been shown to secrete $\alpha$-syn positive exosomes [61]. Moreover, it was found in foetal tissue graft recipients that return of symptoms of a long term graft survivor correlated with classic PD markers such as $\alpha$-syn and ubiquitin aggregation within the grafted region, replicated in patients who received foetal mesencephalic dopaminergic neurons $[62,63]$. 


\subsection{Oxidative Stress}

There is evidence that oxidative stress is increased in normal aged brain however the level of oxidative stress is greatly increased in patients with neurodegenerative diseases [64]. The major contribution to oxidative stress in ageing primates originates from mitochondrial complexes I and III of the electron transport chain leading to greater mitochondrial DNA damage compared to nuclear DNA damage [65]. Quilty et al. [66] showed that when mouse primary neocortical cells were incubated in the absence of antioxidants a subset of neurons exhibited a higher $\alpha$-syn expression and decreased apoptosis. Whereas, Selkoe and co-workers found that prefibrillar $\alpha$-syn promoted complex I-dependent mitochondrial dysfunction [43]. Moreover, in human SHSY-5Y cells, there was no significant difference in the viability of cells with WT $\alpha$-syn overexpression; however the A53T and A30P mutations were more susceptible to oxidative insult [9].

\section{Increased Intracellular $\mathrm{Ca}^{2+}$ Induces $\alpha$-Synuclein Oligomers}

\subsection{The Role of $\mathrm{Ca}^{2+}$ in the Neuron and Age Related Changes}

$\mathrm{Ca}^{2+}$ plays many important roles in normal cellular processes, such as apoptosis, metabolism, signal transduction, gene expression and cell death, and intracellular $\mathrm{Ca}^{2+}$ homeostasis is tightly regulated between the cytoplasm, intracellular $\mathrm{Ca}^{2+}$ stores, such as the endoplamic reticulum (ER), and between the intracellular environment and the extracellular environment. Resting intracellular $\mathrm{Ca}^{2+}$ is found not to be increased with age of the neuron, with studies indicating no difference between intracellular $\mathrm{Ca}^{2+}$ levels of young and aged neurons. However, the return time to resting levels after a stimulus is greatly reduced in aged neurons. Thus, the possible link between $\mathrm{Ca}^{2+}$ and $\alpha$-syn aggregation in neurodegenerative diseases is a current focus of research [67,68]. Indeed, $\alpha$-syn oligomers have been shown to promote $\mathrm{Ca}^{2+}$ influx [42]. Furthermore $\mathrm{Ca}^{2+}$ and $\mathrm{Co}^{2+}$ binding have been shown to accelerate the formation of $\alpha$-syn annular oligomeric species [69]. Although the precise $\mathrm{Ca}^{2+}$ binding site has not yet been defined, truncation at residue 125 was found to abolish $\mathrm{Ca}^{2+}$ binding and $\mathrm{Ca}^{2+}$-dependent aggregation.

The major sources of intracellular $\mathrm{Ca}^{2+}$ include $\mathrm{Ca}^{2+}$ influx through ligand-gated glutamate receptors, such as $\mathrm{N}$-methyl-D-aspartate receptor (NMDAR) or various voltage-dependent $\mathrm{Ca}^{2+}$ channels (VDCCs), as well as the release of $\mathrm{Ca}^{2+}$ from intracellular stores. Clearance of $\mathrm{Ca}^{2+}$ after stimulation is achieved either by intracellular $\mathrm{Ca}^{2+}$ binding, uptake into the ER and mitochondria or pumping into the extracellular space via plasma membrane $\mathrm{Ca}^{2+}$ ATPases, which have been shown to be impaired in aged neurons [70-72]. Aged neurons also exhibit a decreased capacity to recover from $\mathrm{Ca}^{2+}$ stimulus through uptake into the intracellular $\mathrm{Ca}^{2+}$ stores with a decline in sarcoplasmic ER $\mathrm{Ca}^{2+}$ ATPase $\mathrm{Ca}^{2+}$ function [73]. The mitochondrion is a second intracellular $\mathrm{Ca}^{2+}$ store and like the ER, the ability of this organelle to act as a reservoir for $\mathrm{Ca}^{2+}$ is also decreased with age [74].

Calbindin $(\mathrm{CB})$, calretinin and parvalbumin are three cytosolic calcium binding proteins that are capable of $\mathrm{Ca}^{2+}$ buffering in neurons. Bu et al. [75] found a decrease in both calretinin and CB in aged compared to young cortical neurons; put no difference in parvalbumin positive neurons. German et al. [76] found that in both idiopathic PD and in MPTP monkey or mouse models that CB+ neurons were spared. Moreover, calretinin expression in dopaminergic neurons of the SN protected 
against 6-hydroxydopamine [77,78]. Furthermore, Yamada et al. [79] found relative sparing of SN neurons positive for $\mathrm{CB}$ in $\mathrm{PD}$ cases.

\subsection{Increased Intracellular $\mathrm{Ca}^{2+}$ Induces $\alpha$-Synuclein Oligomers}

Recent studies have shown that a transient increase in the intracellular free $\mathrm{Ca}^{2+}$ concentration induced in cultured $1321 \mathrm{~N} 1$ glioma cells by thapsigargin or $\mathrm{Ca}^{2+}$ ionophore (CI) chemical treatments caused a significant increase in the proportion of cells bearing microscopically-visible $\alpha$-syn aggregates (Figure 2A). It was also demonstrated that chelating free $\mathrm{Ca}^{2+}$ with BAPTA, resulted in no significant difference in the number of inclusions between control and CI/BAPTA cells, indicating that raised intracellular free $\mathrm{Ca}^{2+}$ directly induces $\alpha$-syn aggregates. Moreover, supporting studies with recombinant protein indicated that direct binding of $\mathrm{Ca}^{2+}$ ion to $\alpha$-syn promoted rapid oligomer formation in vitro [80], which was not observed with the C-terminally truncated protein (1-125) that lacks the glutamate-rich putative $\mathrm{Ca}^{2+}$ binding domain [69] (see Figure 1). Further studies are needed to map the $\mathrm{Ca}^{2+}$ binding site by mutating each of the putative glutamate residues in this region thought to represent potential metal ligands (see Figure 1). More recently, Follett et al. [81], demonstrated that potassium depolarization of the plasma membrane in HEK293T and SH-SY5Y human cell lines resulted in raised intracellular free $\mathrm{Ca}^{2+}$ and $\alpha$-syn aggregate formation under more physiologically relevant cellular conditions ([81]; Figure 2B). Both raised free $\mathrm{Ca}^{2+}$ and $\alpha$-syn aggregation were blocked by BAPTA chelation treatment (Figure $2 \mathrm{~B}$, centre). Potassium depolarization was observed especially to trigger formation of frequent large, Lewy body-like perinuclear $\alpha$-syn inclusion bodies (Figure 2B, right).

It is clear that raised $\mathrm{Ca}^{2+}$ is an important factor influencing $\alpha$-syn aggregation, and potentially in the formation of the cytotoxic oligomeric species seen in disease. Thus, addition of $\mathrm{Ca}^{2+}$ to $\alpha$-syn monomer in vitro could promote $\alpha$-syn oligomerization and resulted in the rapid formation of potentially toxic annular $\alpha$-syn oligomeric structures [80]. This provides a potential therapeutic target, by using drugs that modulate the amount of free $\mathrm{Ca}^{2+}$ in the cell. $\mathrm{Ca}^{2+}$ channel blockers, such as those from the dihydropyridine family, may be used to lessen the increase in intracellular $\mathrm{Ca}^{2+}$ seen in aged neurons [82]. A step towards replicating the complex architecture of the CNS and assessing $\mathrm{Ca}^{2+}$ blockade was performed by Chan et al. [83] who used brain slices prepared from a MPTP mouse model for PD. They found that by using blocking L-type $\mathrm{Ca}_{\mathrm{v}} 1.3 \mathrm{Ca}^{2+}$ channels with Isradipine, a common drug used to treat high blood pressure, they could recover dopaminergic neural activity. This supports the data of Yamada et al. [79] that dopaminergic neurons of the $\mathrm{SN}$, rich in the $\mathrm{Ca}^{2+}$ binding protein $\mathrm{CB}$, were preferentially spared in control brain sections compared with PD patients and the PD mouse model data showing neurons expressing $\mathrm{CB}$ were spared from pathological loss [84]. Consistent with this, Trimethadione (TMO), a $\mathrm{Ca}^{2+}$ channel blocker with broad selectivity commonly used as an anti-epileptic drug, blocked $\mathrm{K}^{+}$-depolarization induced $\mathrm{Ca}^{2+}$ influx into $\mathrm{SH}-\mathrm{SY} 5 \mathrm{Y}$ cells resulting in loss of $\alpha$-syn positive aggregate formation post-depolarization [81]. Furthermore, recent studies using a unilateral rotenone (oxidative stress) lesion mouse model of PD (described in [85]), also showed improved survival of $\mathrm{CB}+$ neurons and almost exclusive partitioning of $\alpha$-syn aggregates in the $\mathrm{CB}-$ cell population (Figure 3; [86]). In this model, injection of rotenone into the medial forebrain bundle of one brain hemisphere only, allows for comparison of $\alpha$-syn inclusion body positive and $\mathrm{CB}+$ neurons between treated and untreated hemispheres. 
Figure 2. Raised intracellular $\mathrm{Ca}^{2+}$ promotes $\alpha$-syn aggregation. (A) $1321 \mathrm{~N} 1$ human glioma cells treated with either thapsigargin or $\mathrm{Ca}^{2+}$ ionophore caused raised intracellular free $\mathrm{Ca}^{2+}$ and induced $\alpha$-syn aggregates (arrows) after 12-24 h [80]; (B) Potassium depolarization of SH-SY5Y human neuroblastoma and HEK293T cells resulted in transiently raised intracellular free $\mathrm{Ca}^{2+}$ and Lewy body-like large $\alpha$-syn aggregates (arrows) that could be blocked by the BAPTA-AM $\mathrm{Ca}^{2+}$ chelator [81]. (C) Co-treatment of $1321 \mathrm{~N} 1$ cells with thapsigargin (TG) or $\mathrm{Ca}^{2+}$ ionophore $(\mathrm{CI})$ and hydrogen peroxide resulted in increased $\alpha$-syn aggregates (arrows; graph, right); consistent with a cooperative interaction between raised free $\mathrm{Ca}^{2+}$ and oxidative stress [87]. Scale bars, $10 \mu \mathrm{m}$.

\section{N1 glioma cells}

A
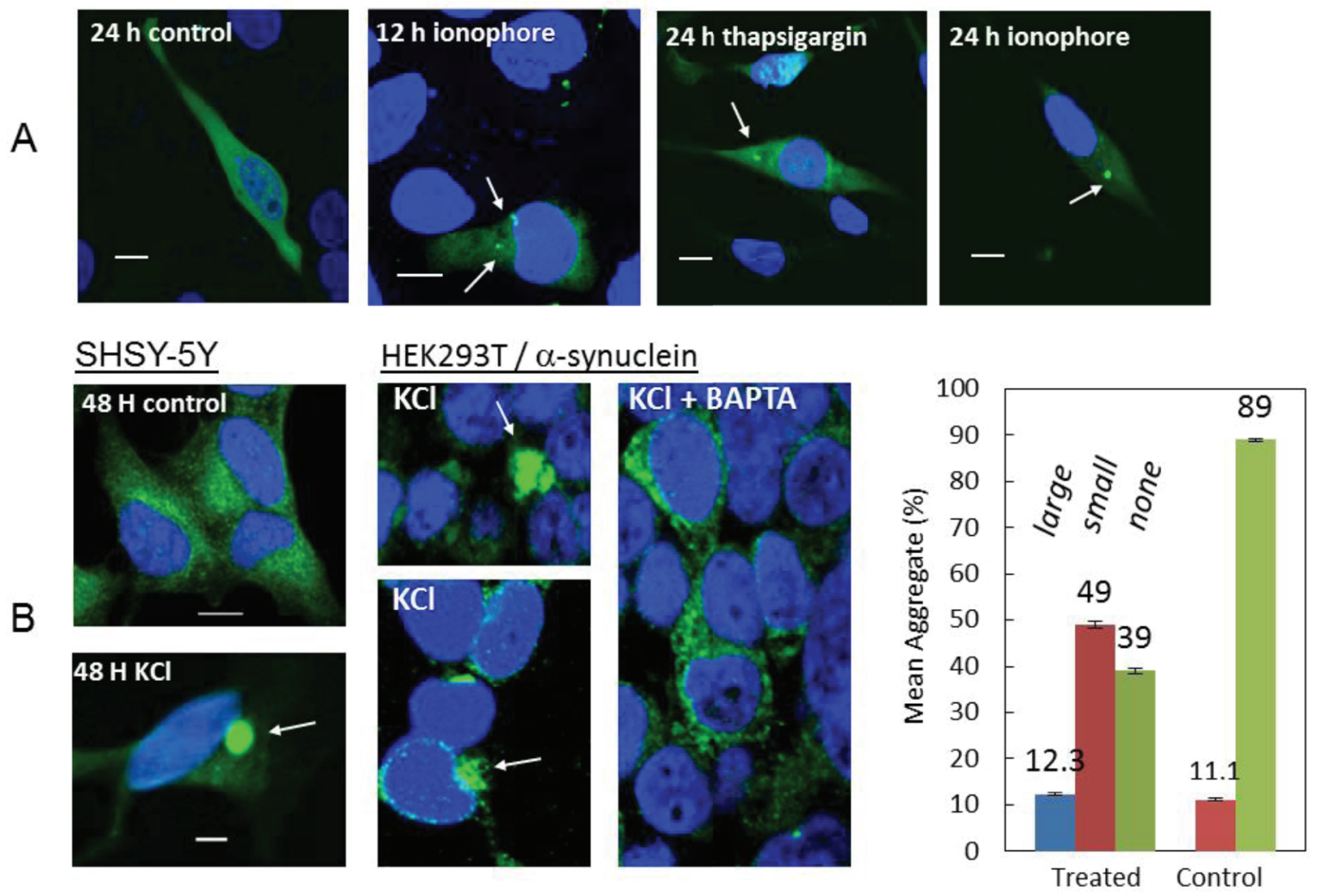

$1321 \mathrm{~N} 1$ glioma cells
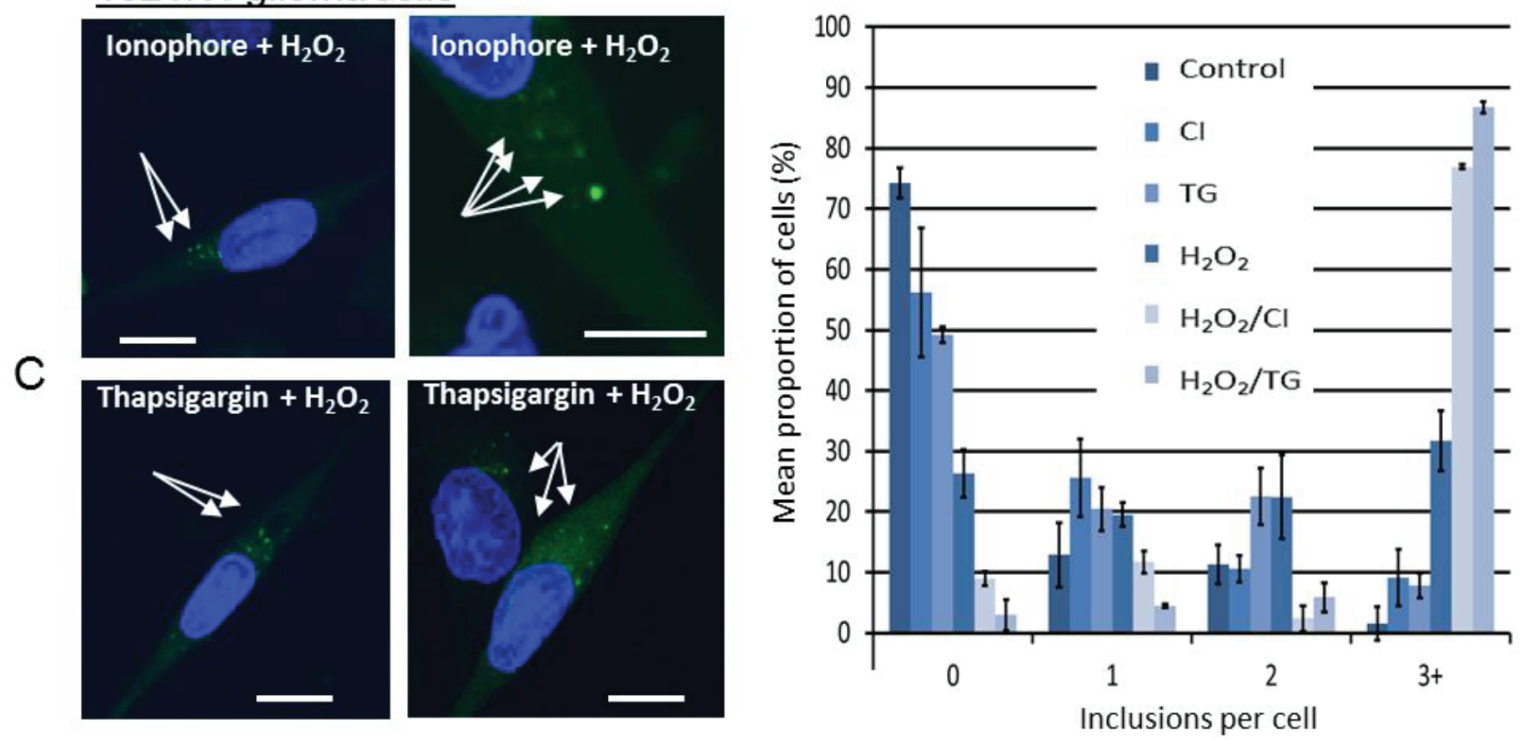
Figure 3. Unilateral rotenone lesion mouse (oxidative stress) model of PD shows $\alpha$-syn aggregates primarily in calbindin-negative neurons. (A) $\mathrm{CB}+$ neurons (arrowheads) showed relative protection in the unilateral rotenone lesion (oxidative stress) model of PD (as detailed in [85]), with more $\mathrm{CB}+$ neurons surviving in the treated than in the untreated hemisphere and partitioning of $\alpha$-syn aggregates (arrow) in the CB- neurons [86]. Scale bar, $50 \mu \mathrm{m}$. (B) Graph of cell counting data shows a significantly greater number of $\alpha$-syn aggregates occur in $\mathrm{CB}-$ neurons than in $\mathrm{CB}+$ neurons.

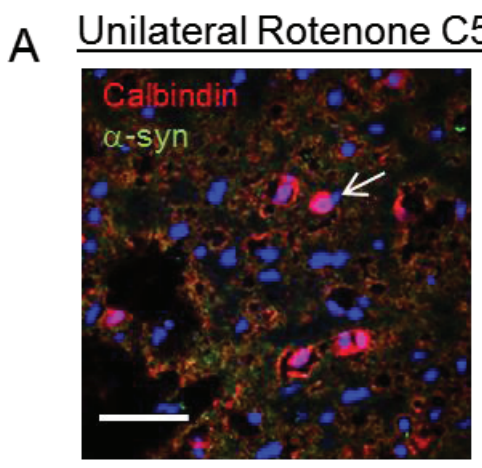

Control Hemisphere

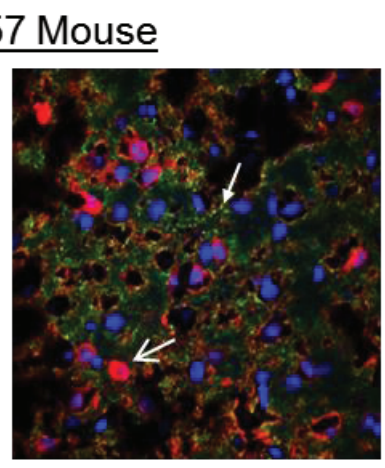

Treated Hemisphere

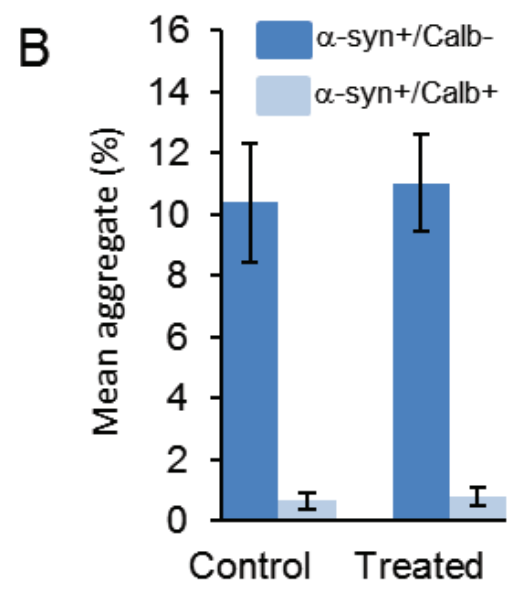

\section{3. $\alpha$-Synuclein Oligomerization Induces Raised $\mathrm{Ca}^{2+}$ and Oxidative Stress}

Elevated levels of intracellular $\alpha$-syn have been shown to elevate levels of intracellular $\mathrm{Ca}^{2+}[88]$. Secreted $\alpha$-syn induces increase in capacitive $\mathrm{Ca}^{2+}$ entry in differentiated SH-SY5Y [89]. Reznichenko et al. [90] investigated $\mathrm{Ca}^{2+}$ dynamics in transgenic (tg) mice expressing human WT $\alpha$-syn. $\alpha$-Syn-tg mice exhibited augmented, long-lasting $\mathrm{Ca}^{2+}$ transients characterized by considerable deviation from the exponential decay. Furthermore control and $\alpha$-syn $\mathrm{KO}$ groups demonstrated low percentages of neurons with $\mathrm{Ca}^{2+}$ abnormalities whereas the $\alpha$-syn tg group showed $\mathrm{Ca}^{2+}$ response alteration, suggesting these alterations are related to $\alpha$-syn expression.

Other studies have shown that $\alpha$-syn overexpression augments mitochondrial $\mathrm{Ca}^{2+}$ transients by enhancing ER-mitochondria interactions. Cali et al. [91] demonstrated that $\alpha$-syn with acidic C-terminal domain overexpression increases mitochondrial $\mathrm{Ca}^{2+}$ in SH-SY5Y and HeLa cells. Additionally, treatment with naturally secreted $\alpha$-syn increases $\mathrm{Ca}^{2+}$ entry in primary rat cortical neurons and induces mitochondrial $\mathrm{Ca}^{2+}$ uptake. Significantly higher levels of mitochondrial $\mathrm{Ca}^{2+}$ content in $\alpha$-syn treated cells were observed compared to control cells.

Dryanovsky et al. [92] found that in $\mathrm{CB}-$ and $\mathrm{CB}+$ dopaminergic neurons having inclusions, mitochondrial oxidant stress levels were higher in the soma and proximal dendrites than in neurons without inclusions. Treatment with isradipine significantly diminished the oxidative stress levels in $\mathrm{CB}-$ dopaminergic neurons. This suggests that the formation of $\alpha$-syn inclusions stimulates ROS production in the cytosol. $\alpha$-Syn provokes an elevation of cytosolic $\mathrm{Ca}^{2+}$ in yeast that coincides with an increase in oxidative stress [93], suggesting that $\alpha$-syn aggregation leads to an increase in mitochondrial $\mathrm{Ca}^{2+}$ transient and then to oxidative stress. WT $\alpha$-syn has also been shown to induce mitochondrial NO when it is associated with mitochondria [94]. This indicates that not only will normal increases in oxidative stress cause aggregation but that aggregation of $\alpha$-syn also induces more oxidative stress 
within the cell forming a positive feedback loop. However, this is contrary to other research which shows that $\alpha$-syn protects cells from oxidative stress by inactivating the c-Jun $N$-terminal kinase (JNK) pathway [95].

\subsection{Synergistic Effect of $\mathrm{Ca}^{2+}$ and Oxidative Stress}

Oxidative stress is strongly implicated in $\alpha$-synucleinopathy and may combine synergistically with other factors, such as $\alpha$-syn expression and raised $\mathrm{Ca}^{2+}$, to promote $\alpha$-syn aggregation and neurodegeneration. The combination of oxidative stress and $\alpha$-syn expression has been used to generate a model of MSA in mice, whereby the overexpression of $\alpha$-syn in glial cells is combined with 3-nitropropionic acid [96]. Moreover, recent studies have examined the role of oxidative stress in the formation of potentially toxic $\alpha$-syn oligomeric species in conjunction with $\mathrm{Ca}^{2+}$ binding. It was found that, when treated with $\mathrm{Ca}^{2+}$ ionophore (CI) or thapsigargin (TG) and $\mathrm{H}_{2} \mathrm{O}_{2}$ in combination, there was a dramatic increase in the number of protein aggregates per cell in $1321 \mathrm{~N} 1$ cells (Figure 2). This was also reflected in in vitro experiments that showed that the combination of $\mathrm{Ca}^{2+}$ treatment and oxidation of recombinant $\alpha$-syn monomer caused the formation of stable, oligomeric $\alpha$-syn aggregates, indicating a cooperative interaction between $\mathrm{Ca}^{2+}$ binding to $\alpha$-syn and $\alpha$-syn oxidation [87]. Thus, these recent findings have indicated that increased intracellular free $\mathrm{Ca}^{2+}$ and oxidative stress work synergistically to induce $\alpha$-syn aggregation. This may be extremely important in the pathogenic mechanisms behind $\alpha$-syn aggregation and $\alpha$-synopthathy disease progression as fibrillization of $\alpha$-syn is highly dependent on nucleation centres, with pre-aggregated $\alpha$-syn dramatically increasing the rate of $\alpha$-syn aggregation. Furthermore, kinetic studies of $\alpha$-syn aggregation by Nath et al. [97] were consistent with an auto-catalytic mechanism. Thus, $\mathrm{Ca}^{2+}$ /oxidation stabilized $\alpha$-syn aggregates may serve to increase nucleation centres in disease. Indeed, the formation of di-tyrosine cross linked $\alpha$-syn dimers have been found previously to be a rate-limiting step in the fibrillation process and the formation of nucleation centres [98]. Moreover, $\mathrm{Ca}^{2+}$ influx into neurons can induce oxidative stress in mitochondria of mouse dopaminergic neurons [99], as oxidative stress induced by $\mathrm{Ca}^{2+}$ influx was exacerbated in DJ-1 mutant mice.

\section{Conclusions: Targeting Calcium with Future Therapeutics}

The link between PD and some atypical Parkinson's syndromes and aggregation of $\alpha$-syn makes this process a major target for the development of future neurodegenerative therapies. Many triggers for pathological $\alpha$-syn aggregation have been identified, including raised $\mathrm{Ca}^{2+}$ and oxidative stress. Recent studies have found that transient increases of intracellular $\mathrm{Ca}^{2+}$ induce cytoplasmic $\alpha$-syn aggregates, that can be blocked by $\mathrm{Ca}^{2+}$ buffering or $\mathrm{Ca}^{2+}$ channel blocking agents. Furthermore, it has been shown that $\mathrm{Ca}^{2+}$ and oxidative stress cooperatively promote $\alpha$-syn aggregation. These recent findings suggest an association between raised intracellular $\mathrm{Ca}^{2+}, \alpha$-syn aggregation and neurotoxicity paving the way for the development of therapeutics that target raised $\mathrm{Ca}^{2+}[100]$. Since $\mathrm{Ca}^{2+}$ lowering medications, such as anti-epileptic drugs, often have significant side-effects, successfully targeting raised intracellular free $\mathrm{Ca}^{2+}$ in the brain as a neuroprotective strategy will depend on the development of reliable genetic, imaging or biochemical tests. It is clear that in order to differentiate disease sub-types with strong $\mathrm{Ca}^{2+}$ involvement, multiple marker evaluation will be necessary. 


\section{Acknowledgments}

We are grateful to the Australian Research Council, Griffith Health Institute and the Clem Jones Foundation for financial support.

\section{Author Contributions}

Alex Rcom-H'cheo-Gauthier, Jacob Goodwin and Dean L. Pountney each contributed equally to the writing of this review article. Alex Rcom-H'cheo-Gauthier and Dean L. Pountney contributed unpublished data as indicated.

\section{Conflicts of Interest}

The authors declare no conflict of interest.

\section{References}

1. Goedert, M.; Spillantini, M.G.; del Tredici, K.; Braak, H. 100 years of Lewy pathology. Nat. Rev. Neurol. 2013, 9, 13-24.

2. Eschbach, J.; Danzer, K.M. $\alpha$-Synuclein in Parkinson's disease: Pathogenic function and translation into animal models. Neurodegener. Dis. 2014, 14, 1-17.

3. Radford, R.; Wong, M.B.; Pountney, D.L. Neurodegenerative aspects of multiple system atrophy. In Handbook of Neurotoxicity; Kostrzewa, R.M., Ed.; Springer: New York, NY, USA, 2014; pp. 2157-2180.

4. Krüger, R.; Kuhn, W.; Müller, T.; Woitalla, D.; Graeber, M.; Kösel, S.; Przuntek, H.; Epplen, J.T.; Schöls, L.; Riess, O. Ala30Pro mutation in the gene encoding alpha-synuclein in Parkinson's disease. Nat. Genet. 1998, 18, 106-108.

5. Polymeropoulos, M.H.; Lavedan, C.; Leroy, E.; Ide, S.E.; Dehejia, A.; Dutra, A.; Pike, B.; Root, H.; Rubenstein, J.; Boyer, R.; et al. Mutation in the alpha-synuclein gene identified in families with Parkinson's disease. Science 1997, 276, 2045-2047.

6. Zarranz, J.J.; Alegre, J.; Gómez-Esteban, J.C.; Lezcano, E.; Ros, R.; Ampuero, I.; Vidal, L.; Hoenicka, J.; Rodriguez, O.; Atarés, B.; et al. The new mutation, E46K, of alpha-synuclein causes Parkinson and Lewy body dementia. Ann. Neurol. 2004, 55, 164-173.

7. Lesage, S.; Anheim, M.; Letournel, F.; Bousset, L.; Honore, A.; Rozas, N.; Pieri, L.; Madiona, K.; Durr, A.; Melki, R.; et al. G51D a-Synuclein mutation causes a novel parkinsonian-pyramidal syndrome. Ann. Neurol. 2013, 73, 459-471.

8. Proukakis, C.; Dudzik, C.G.; Brier, T.; MacKay, D.S.; Cooper, J.M.; Millhauser, G.L.; Houlden, H.; Schapira, A.H. A novel $\alpha$-synuclein missense mutation in Parkinson disease. Neurology 2013, 80, 1062-1064.

9. Kanda, S.; Bishop, J.F.; Eglitis, M.A.; Yang, Y.; Mouradian, M.M. Enhanced viability to oxidative stress by alpha-synuclein mutations and C-terminal truncation. Neuroscience 2000, 97, 279-284.

10. Narhi, L.; Wood, S.J.; Steavenson, S.; Jiang, Y.; Wu, G.M.; Anafi, D.; Kaufman, S.A.; Martin, F.; Sitney, K.; Denis, P.; et al. Both familial Parkinson's disease mutations accelerate alpha-synuclein aggregation. J. Biol. Chem. 1999, 274, 9843-9846. 
11. Khalaf, O.; Fauvet, B.; Oueslati, A.; Dikiy, I.; Mahul-Mellier, A.L.; Ruggeri, F.S.; Mbefo, M.; Vercruysse, F.; Dietler, G.; Lee, S.J.; et al. The H50Q mutation enhances $\alpha$-synuclein aggregation, secretion and toxicity. J. Biol. Chem. 2014, doi:10.1074/jbc.M114.553297.

12. Ibáñez, P.; Bonnet, A.M.; Débarges, B.; Lohmann, E.; Tison, F.; Pollak, P.; Agid, Y.; Dürr, A.; Brice, A. Causal relation between alpha-synuclein gene duplication and familial Parkinson's disease. Lancet 2004, 364, 1169-1171.

13. Singleton, A.B.; Farrer, M.; Johnson, J.; Singleton, A.; Hague, S.; Kachergus, J.; Hulihan, M.; Peuralinna, T.; Dutra, A.; Nussbaum, R.; et al. alpha-Synuclein locus triplication causes Parkinson's disease. Science 2003, doi:10.1126/science.1090278.

14. Tanner, C.M.; Kamel, F.; Ross, W.; Hoppin, J.A.; Goldman, S.M.; Korell, M.; Marras, C.; Bhudhikanok, G.S.; Kasten, M.; Chade, A.R.; et al. Rotenone, paraquat, and Parkinson's disease. Environ. Health Perspect. 2011, 119, 866-872.

15. Wang, X.; Su, B.; Liu, W.; He, X.; Gao, Y.; Castellani, R.J.; Perry, G.; Smith, M.A.; Zhu, X. DLP1-dependent mitochondrial fragmentation mediates 1-methyl-4-phenylpyridinium toxicity in neurons: Implications for Parkinson's disease. Ageing Cell. 2011, 10, 807-823.

16. Hernán, M.A.; Takkouche, B.; Caamaño-Isorna, F.; Gestal-Otero, J.J. A meta-analysis of coffee drinking, cigarette smoking, and the risk of Parkinson's disease. Ann. Neurol. 2002, 52, 276-284.

17. Spillantini, M.G.; Schmidt, M.L.; Lee, V.M.; Trojanowski, J.Q.; Jakes, R.; Goedert, M. Alpha-synuclein in Lewy bodies. Nature 1997, 388, 839-840.

18. Al-Chalabi, A.; Dürr, A.; Wood, N.W.; Parkinson, M.H.; Camuzat, A.; Hulot, J.S.; Morrison, K.E.; Renton, A.; Sussmuth, S.D.; Landwehrmeyer, B.G.; et al. Genetic variants of the alpha-synuclein gene $S N C A$ are associated with multiple system atrophy. PLoS One 2009, 4, e7114.

19. Hanna, P.A.; Jankovic, J.; Kirkpatrick, J.B. Multiple system atrophy: The putative causative role of environmental toxins. Arch. Neurol. 1999, 56, 90-94.

20. Vidal, J.S.; Vidailhet, M.; Elbaz, A.; Derkinderen, P.; Tzourio, C.; Alpérovitch, A. Risk factors of multiple system atrophy: A case-control study in French patients. Mov. Disord. 2008, 23, 797-803.

21. Iwai, A.; Masliah, E.; Yoshimoto, M.; Ge, N.; Fianagan, L.; Rohan de Silva, H.A.; Kittei, A.; Saitoh, T. The precursor protein of non-a $\beta$ component of Alzheimer's disease amyloid is a presynaptic protein of the central nervous system. Neuron 1995, 14, 467-475.

22. Maroteaux, L.; Campanelli, J.T.; Scheller, R.H. Synuclein: A neuron-specific protein localized to the nucleus and presynaptic nerve terminal. J. Neurosci. 1998, 8, 2804-2815.

23. Clayton, D.F.; George, J.M. Synucleins in synaptic plasticity and neurodegenerative disorders. J. Neurosci. Res. 1999, 58, 120-129.

24. Burré, J.; Sharma, M.; Tsetsenis, T.; Buchman, V.; Etherton, M.R.; Südhof, T.C. Alpha-synuclein promotes SNARE-complex assembly in vivo and in vitro. Science 2010, 329, 1663-1667.

25. Nielsen, M.S.; Vorum, H.; Lindersson, E.; Jensen, P.H. $\mathrm{Ca}^{2+}$ binding to alpha-synuclein regulates ligand binding and oligomerization. J. Biol. Chem. 2001, 276, 22680-22684.

26. Giasson, B.I.; Murray, I.V.; Trojanowski, J.Q.; Lee, V.M. A hydrophobic stretch of 12 amino acid residues in the middle of alpha-synuclein is essential for filament assembly. J. Biol. Chem. 2001, 276, 2380-2386. 
27. Eliezer, D.; Kutluay, E.; Bussell, R., Jr.; Browne, G. Conformational properties of alpha-synuclein in its free and lipid-associated states. J. Mol. Biol. 2001, 307, 1061-1073.

28. Davidson, W.S.; Jonas, A.; Clayton, D.F.; George, J.M. Stabilization of alpha-synuclein secondary structure upon binding to synthetic membranes. J. Biol. Chem. 1998, 273, 9443-9449.

29. Wietek, J.; Haralampiev, I.; Amoussouvi, A.; Herrmann, A.; Stöckl, M. Membrane bound $\alpha$-synuclein is fully embedded in the lipid bilayer while segments with higher flexibility remain. FEBS Lett. 2013, 587, 2572-2577.

30. Wood, S.J.; Wypych, J.; Steavenson, S.; Lousis, J-C.; Citron, M.; Biere, A.L. $\alpha$-Synuclein fibrillogenesis is nucleation dependent: Implications for the pathogenesis of Parkinson's disease. J. Biol. Chem. 1999, 274, 19509-19512.

31. Zibaee, S.; Jakes, R.; Fraser, G.; Serpell, L.C.; Crowther, R.A.; Goedert, M. Sequence determinants for amyloid fibrillogenesis of human alpha-synuclein. J. Mol. Biol. 2007, 374, 454-464.

32. Narayanan, V.; Scarlata, S. Membrane binding and self-association of alpha-synucleins. Biochemistry 2001, 40, 9927-9934.

33. Lokappa, S.B.; Suk, J.E.; Balasubramanian, A.; Samanta, S.; Situ, A.J.; Ulmer, T.S. Sequence and membrane determinants of the random coil-helix transition of $\alpha$-synuclein. $J$. Mol. Biol. 2014, 426, 2130-2144.

34. McLean, P.J.; Kawamata, H.; Ribich, S.; Hyman, T. Membrane association and protein conformation of $\alpha$-synuclein in intact neurons. J. Biol. Chem. 2000, 275, 8812-8816.

35. Chen, R.H.; Wislet-Gendebien, S.; Samuel, F.; Visanji, N.P.; Zhang, G.; Marsilio, D.; Langman, T.; Fraser, P.E.; Tandon, A. $\alpha$-Synuclein membrane association is regulated by the Rab3a recycling machinery and presynaptic activity. J. Biol. Chem. 2013, 288, 7438-7449.

36. Mak, S.R.; McCormack, A.L.; Langston, J.W.; Kordower, J.H.; di Monte, D.A. Decreased $\alpha$-synuclein expression in the ageing mouse substantia nigra. Exp. Neurobiol. 2009, 220, 359-365.

37. Grundemann, J.; Schlaudraff, F.; Haeckel, O.; Liss, B. Elevated $\alpha$-synuclein mRNA levels in individual UV-laser-microdissected dopaminergic substantia nigra neurons in Idiopathic Parkinson's disease. Nucleic Acids Res. 2008, 36, e38.

38. Outeiro, T.F.; Putcha, P.; Tetzlaff, J.E.; Spoelgen, R.; Koker, M.; Carvalho, F.; Hyman, B.T.; McLean, P.J. Formation of toxic oligomeric alpha-synuclein species in living cells. PLoS One 2008, 3, e1867.

39. Esteves, A.R.; Arduíno, D.M.; Silva, D.F.; Oliveira, C.R.; Cardoso, S.M. Mitochondrial dysfunction: The Road to alpha-synuclein oligomerization in PD. Parkinsons Dis. 2011, doi:10.4061/2011/693761.

40. Kalia, L.V.; Kalia, S.K.; McLean, P.J.; Lozano, A.M.; Lang, A.E. $\alpha$-Synuclein oligomers and clinical implications for Parkinson disease. Ann. Neurol. 2013, 73, 155-169.

41. Yasuda, T.; Nakata, Y.; Mochizuki, H. $\alpha$-Synuclein and neuronal cell death. Mol. Neurobiol. 2013, 47, 466-483.

42. Luth, E.S.; Stavrovskaya, I.G.; Bartels, T.; Kristal, B.S.; Selkoe, D.J. Soluble, prefibrillar $\alpha$-synuclein oligomers promote complex I-dependent, $\mathrm{Ca}^{2+}$-induced mitochondrial dysfunction. J. Biol. Chem. 2014, doi:10.1074/jbc.M113.545749. 
43. Danzer, K.M.; Haasen, D.; Karow, A.R.; Moussaud, S.; habeck, M.; Giese, A.; Kretzschmar, H.; Hengerer, B.; Kostka, M. Different species of alpha-synuclein oligomers induce calcium influx and seeding. J. Neurosci. 2007, 27, 9220-9232.

44. Bartels, T.; Choi, J.C.; Selkoe, D.J. $\alpha$-Synuclein occurs physiologically as a helically folded tetramer that resists aggregation. Nature 2011, 477, 107-111.

45. Wang, W.; Perovic, W.; Chittuluru, J.; Kaganovich, A.; Nguyen, L.T.T.; Liao, J.; Auclair, J.R.; Johnson, D.; Landeru, D.; Simorellis, A.K.; et al. A soluble $\alpha$-synuclein construct forms a dynamic tetramer. Proc. Natl. Acad. Sci. USA 2011, 108, 17797-17802.

46. Smith, W.W.; Margolis, R.L.; Li, X.; Troncoso, J.C.; Lee, M.K.; Dawson, V.L.; Dawson, T.M.; Iwatsubo, T.; Ross, C.A. Alpha-synuclein phosphorylation enhances eosinophilic cytoplasmic inclusion formation in SH-SY5Y cells. J. Neurosci. 2005, 25, 5544-5552.

47. Lu, Y.; Prudent, M.; Fauvet, B.; Lashuel, H.A.; Girault, H.H. Phosphorylation of $\alpha$-Synuclein at Y125 and S129 alters its metal binding properties: Implications for understanding the role of $\alpha$-synuclein in the pathogenesis of Parkinson's disease and related disorders. ACS Chem. Neurosci. 2011, 2, 667-675.

48. Liu, L.L.; Franz, K.J. Phosphorylation of an alpha-synuclein peptide fragment enhances metal binding. J. Am. Chem. Soc. 2005, 127, 9662-9663.

49. Anderson, J.P.; Walker, D.E.; Goldstein, J.M.; de Laat, R.; Banducci, K.; Caccavello, R.J.; Barbour, R.; Huang, J.; Kling, K.; Lee, M.; et al. Phosphorylation of Ser-129 is the dominant pathological modification of alpha-synuclein in familial and sporadic Lewy body disease. J. Biol. Chem. 2006, 281, 29739-29752.

50. Uversky, V.N.; Yamin, G.; Munishkina, L.A.; Karymov, M.A.; Millett, I.S.; Doniach, S.; Lyubchenko, Y.L.; Fink, A.L. Effects of nitration on the structure and aggregation of alpha-synuclein. Mol. Brain Res. 2005, 134, 84-102.

51. Chavarría, C.; Souza, J.M. Oxidation and nitration of $\alpha$-synuclein and their implications in neurodegenerative diseases. Arch. Biochem. Biophys. 2013, 533, 25-32.

52. Glaser, C.B.; Yamin, G.; Uversky, V.N.; Fink, A.L. Methionine oxidation, alpha-synuclein and Parkinson's disease. Biochim. Biophys. Acta 2005, 1703, 157-169.

53. Uversky, V.N.; Yamin, G.; Souillac, P.O.; Goers, J.; Glaser, C.B.; Fink, A.L. Methionine oxidation inhibits fibrillation of human alpha-synuclein in vitro. FEBS Lett. 2002, 517, 239-244.

54. Feany, M.B.; Bender, W.W. A Drosophila model of Parkinson's disease. Nature 2000, 404, 394-398.

55. Kaul, S.; Anantharam, V.; Kanthasamy, A.; Kanthasamy, A.G. Wild-type alpha-synuclein interacts with pro-apoptotic proteins PKCdelta and BAD to protect dopaminergic neuronal cells against MPP+-induced apoptotic cell death. Brain Res. Mol. Brain Res. 2005, 139, 137-152.

56. Pham, C.L.; Cappai, R. The interplay between lipids and dopamine on $\alpha$-synuclein oligomerization and membrane binding. Biosci. Rep. 2013, 33, e00074.

57. Lee, H.J.; Bae, E.J.; Lee, S.J. Extracellular $\alpha$-synuclein-A novel and crucial factor in Lewy body diseases. Nat. Rev. Neurol. 2014, 10, 92-98.

58. Alvarez-Erviti, L.; Seow, Y.; Schapira, A.H.; Gardiner, C.; Sargent, I.L.; Wood, M.J.; Cooper, J.M. Lysosomal dysfunction increases exosome-mediated alpha-synuclein release and transmission. Neurobiol. Dis. 2011, 42, 360-367. 
59. Danzer, K.M.; Kranich, L.R.; Ruf, W.P.; Cagsal-Getkin, O.; Winslow, A.R.; Zhu, L.; Vanderburg, C.R.; McLean, P.J. Exosomal cell-to-cell transmission of alpha synuclein oligomers. Mol. Neurodegener. 2012, doi:10.1186/1750-1326-7-42.

60. Kovacs, G.G.; Breydo, L.; Green, R.; Kis, V.; Puska, G.; Lőrincz, P.; Perju-Dumbrava, L.; Giera, R.; Pirker, W.; Lutz, M.; et al. Intracellular processing of disease-associated $\alpha$-synuclein in the human brain suggests prion-like cell-to-cell spread. Neurobiol. Dis. 2014, doi:10.1016/j.nbd.2014.05.020.

61. Chang, C.; Lang, H.; Geng, N.; Wang, J.; Li, N.; Wang, X. Exosomes of BV-2 cells induced by alpha-synuclein: Important mediator of neurodegeneration in PD. Neurosci. Lett. 2013, 26, 190-195.

62. Kordower, J.H.; Chu, Y.; Hauser, R.A.; Freeman, T.B.; Olanow, C.W. Lewy body-like pathology in long-term embryonic nigral transplants in Parkinson's disease. Nat. Med. 2008, 14, 504-506.

63. Li, J.Y.; Englund, E.; Holton, J.L.; Soulet, D.; Hagell, P.; Lees, A.J.; Lashley, T.; Quinn, N.P.; Rehncrona, S.; Bjorklund, A.; et al. Lewy bodies in grafted neurons in subjects with Parkinson's disease suggest host-to-graft disease propagation. Nat. Med. 2008, 14, 501-503.

64. Sims-Robertson, C.; Hur, J.; Hayes, J.M.; Dauch, J.R.; Keller, P.J.; Brooks, S.V.; Feldman, E.L. The role of oxidative stress in nervous system aging. PLoS One 2013, 8, e68011.

65. Castro, R.; Suarez, E.; Kraiselburd, E.; Isidro, A.; Paz, J.; Ferder, L.; Ayala-Torres, S. Aging increases mitochondrial DNA damage and oxidative stress in liver of rhesus monkeys. Exp. Gerentol. 2012, 47, 29-37.

66. Quilty, M.C.; King, A.E.; Gai, W.P.; Pountney, D.L.; West, A.K.; Vickers, J.C.; Dickson, T.C. Alpha-synuclein is upregulated in neurons in response to chronic oxidative stress and is associated with neuroprotection. Exp. Neurol. 2006, 199, 249-256.

67. Surmeier, D.J.; Schumacker, P.T. Calcium, bioenergetics, and neuronal vulnerability in Parkinson's disease. J. Biol. Chem. 2013, 288, 10736-10741.

68. Fairless, R.; Williams, S.K.; Diem, R. Dysfunction of neuronal calcium signalling in neuroinflammation and neurodegeneration. Cell Tissue Res. 2013, doi:10.1007/s00441-013-1758-8.

69. Lowe, R.; Pountney, D.L.; Jensen, P.H.; Gai, W.P.; Voelcker, N.H. Calcium(II) selectively induces alpha-synuclein annular oligomers via interaction with the C-terminal domain. Protein Sci. 2004, 13, 3245-3252.

70. Brini, M.; Calì, T.; Ottolini, D.; Carafoli, E. Neuronal calcium signaling: Function and dysfunction. Cell. Mol. Life Sci. 2014, doi:10.1007/s00018-013-1550-7.

71. Michaelis, M.L.; Bigelow, D.J.; Schöneich, C.; Williams, T.D.; Ramonda, L.; Yin, D.; Hühmer, A.F.; Yao, Y.; Gao, J.; Squier, T.C. Decreased plasma membrane calcium transport activity in aging brain. Life Sci. 1996, 59, 405-412.

72. Duckles, S.P.; Tsai, H.; Buchholz, J.N. Evidence for decline in intracellular calcium buffering in adrenergic nerves of aged rats. Life Sci. 1996, 58, 2029-2035.

73. Schwaller, B. Calretinin: From a "simple" $\mathrm{Ca}^{2+}$ buffer to a multifunctional protein implicated in many biological processes. Front. Neuroanat. 2014, doi:10.3389/fnana.2014.00003.

74. Perier, C.; Vila, M. Mitochondrial biology and Parkinson's disease. Cold Spring Harb. Prospect. Med. 2012, doi:10.1101/cshperspect.a009332. 
75. Bu, J.; Sathyendra, V.; Nagykery, N.; Geula, C. Age-related changes in calbindin-D28k, calretinin, and parvalbumin-immunoreactive neurons in the human cerebral cortex. Exp. Neurol. 2003, 182, 220-231.

76. German, D.C.; Manaye, K.F.; Sonsalla, P.K.; Brooks, B.A. Midbrain dopaminergic cell loss in Parkinson's disease and MPTP-induced Parkinsonism: Sparing of calbindin-D 28K containing cells. Ann. NY Acad. Sci. 1992, 648, 42-62.

77. Tsuboi, K.; Kimber, T.A.; Shults, C.W. Calretinin-containing axon and neurons are resistant to intrastriatal 6-hydroxydopamine. Brain Res. 2000, 866, 55-64.

78. Kim, B.G.; Shin, D.H.; Jeon, G.S.; Seo, J.H.; Kim, Y.W.; Jeon, B.S.; Cho, S.S. Relative sparing of calretinin containin neurons in the substantia nigra of 6-OHDA treated rat Parkinsonian model. Brain Res. 2000, 7, 162-165.

79. Yamada, T.; McGeer, P.L.; Bainbridge, K.G.; McGeer, E.C. Relative sparing in Parkinson's disease of substantia nigra dopamine neurons containing calbindin-D28K. Brain Res. 1990, 526, 303-307.

80. Nath, S.; Goodwin, J.; Engelborghs, Y.; Pountney, D.L. Raised calcium promotes $\alpha$-synuclein aggregate formation. Mol. Cell. Neurosci. 2011, 46, 516-526.

81. Follett, J.; Darlow, B.; Wong, M.B.; Goodwin, J.; Pountney, D.L. Potassium depolarization and raised calcium induces $\alpha$-synuclein aggregates. Neurotox. Res. 2013, 23, 378-392.

82. Kopecky, B.J.; Liang, R.; Bao, J. T-type calcium channel blockers as neuroprotective agents. Eur. J. Physiol. 2014, 466, 757-765.

83. Chan, S.C.; Guzman, J.N.; Ilijic, E.; Mecer, J.N.; Rick, C.; Tkatch, T.; Meredith, G.E.; Surmeier, D.J. "Rejuvenation" protects neurons in mouse models of Parkinson's disease. Nature 2007, 447, 1081-1089.

84. Gasper, P.; Ben Jelloun, N.; Febvret, A. Sparing of the dopaminergic neurons containing calbindin-D28k and the loss of dopaminergic mesocortical projections in weaver mice. Neuroscience 1994, 61, 293-305.

85. Weetman, J.; Wong, M.B.; Sharry, S.; Rcom-H'cheo-Gauthier, A.; Gai, W.P.; Meedeniya, A.; Pountney, D.L. Increased SUMO-1 expression in the unilateral rotenone-lesioned mouse model of Parkinson's disease. Neurosci. Lett. 2013, 544, 119-124.

86. Rcom-H'cheo-Gauthier, A.; Meedeniya, A.; Pountney, D.L. School of Medical Science, Griffith University, Gold Coast, Australia. Unpublished work, 2014.

87. Goodwin, J.; Nath, S.; Engelborghs, Y.; Pountney, D.L. Raised calcium and oxidative stress cooperatively promote alpha-synuclein aggregate formation. Neurochem. Int. 2013, 62, 703-711.

88. Hettiarachchi, N.T.; Parker, A.; Dallas, M.L.; Pennington, K.; Hung, C.C.; Pearson, H.A.; Boyle, J.P.; Robinson, P.; Peers, C. $\alpha$-Synuclein modulation of $\mathrm{Ca}^{2+}$ signaling in human neuroblastoma (SH-SY5Y) cells. J. Neurochem. 2009, 111, 1192-1201.

89. Melachroinou, K.; Xilouri, M.; Emmanouilidou, E.; Masgrau, R.; Papazafiri, P.; Stefanis, L.; Vekrellis, K. Deregulation of calcium homeostasis mediates secreted alpha-synuclein-induced neurotoxicity. Neurobiol. Aging 2013, 34, 2853-2865.

90. Reznichenko, L.; Cheng, Q.; Nizar, K.; Gratiy, S.L.; Saisan, P.A.; Rockenstein, E.M.; González, T.; Patrick, C.; Spencer, B.; Desplats, P.; et al. In vivo alterations in calcium buffering capacity in transgenic mouse model of synucleinopathy. J. Neurosci. 2012, 32, 9992-9998. 
91. Cali, T.; Ottolini, D.; Negro, A.; Brini, M. alpha-Synuclein controls mitochondrial calcium homeostasis by enhancing endoplasmic reticulum-mitochondria interactions. J. Biol. Chem. 2012, 287, 17914-17929.

92. Dryanovski, D.I.; Guzman, J.N.; Xie, Z.; Galteri, D.J.; Volpicelli-Daley, L.A.; Lee, V.M.; Miller, R.J.; Scumacker, P.T.; Surmeier, D.J. Calcium entry and alpha-synuclein inclusions elevate dendritic mitochondrial oxidant stress in dopaminergic neurons. J. Neurosci. 2013, 33, 10154-10164.

93. Buttner, S.; Faes, L.; Reichelt, W.N.; Broeskamp, F.; Habernig, L.; Benke, S.; Kourtis, N.; Ruli, D.; Carmona-Gutierrez, D.; Eisenberg, T.; et al. The $\mathrm{Ca}^{2+} / \mathrm{Mn}^{2+}$ ion-pump PMR1 links elevation of cytosolic $\mathrm{Ca}^{2+}$ levels to alpha-synuclein toxicity in Parkinson's disease models. Cell Death Differ. 2013, 20, 465-477.

94. Parihar, M.S.; Parihar, A.; Fujita, M.; Hashimoto, M.; Ghafourifar, P. Mitochondrial association of alpha-synuclein causes oxidative stress. Cell. Mol. Life Sci. 2008, 65, 1272-1284.

95. Hashimoto, M.; Hsu, L.J.; Rockenstein, E.; Takenouchi, T.; Mallory, M.; Masliah, E. $\alpha$-Synuclein protects against oxidative stress via inactivation of the c-Jun N-terminal kinase stress-signalling pathway in neuronal cells. J. Biol. Chem. 2002, 277, 11465-11472.

96. Stefanova, N.; Reindl, M.; Neumann, M.; Haass, C.; Poewe, W.; Kahle, P.J.; Wenning, G.K. Oxidative stress in transgenic mice with oligodendroglial $\alpha$-synuclein overexpression replicates the characteristic neuropathology of multiple system atrophy. Am. J. Pathol. 2005, 166, 869-876.

97. Nath, S.; Meuvis, J.; Hendrix, J.; Carl, S.A.; Engelborghs, Y. Early aggregation steps in alpha-synuclein as measured by FCS and FRET: Evidence for a contagious conformational change. Biophys. J. 2010, 98, 1302-1311.

98. Krishnan, S.; Chi, E.Y.; Wood, S.J.; Kendrick, B.S.; Li, C.; Garzon-Rodrigues, W.; Wypych, J.; Randolph, T.W.; Narhi, L.O.; Biere, A.L.; et al. Oxidative dimer formation is the critical rate-limiting step for Parkinson's disease $\alpha$-synuclein fibrillogenesis. Biochemistry 2003, 42, 829-837.

99. Goldberg, J.A.; Guzman, J.N.; Estep, C.M.; Ilijic, E.; Kondapalli, J.; Sanchez-Padilla, J.; Surmerier, D.J. Calcium entry induces mitochondrial oxidant stress in vagal neurons at risk in Parkinson's disease. Nat. Neurosci. 2012, 15, 1414-1421.

100. Schapira, A.H.; Olanow, C.W.; Greenamyre, J.T.; Bezard, E. Slowing of neurodegeneration in Parkinson's disease and Huntington's disease: Future therapeutic perspectives. Lancet 2014, doi:10.1016/S0140-6736(14)61010-2.

2014 by the authors; licensee MDPI, Basel, Switzerland. This article is an open access article distributed under the terms and conditions of the Creative Commons Attribution license (http://creativecommons.org/licenses/by/3.0/). 